\title{
Salty kimberlite of the Udachnaya-East pipe (Yakutia, Russia): a petrological oddity, victim of contamination or a new magma type?
}

\author{
Vadim S. Kamenetsky ${ }^{1}$, Maya B. Kamenetsky ${ }^{1}$, Alexander V. Golovin ${ }^{2}$, Roland Maas ${ }^{3}$, \\ Victor V. Sharygin ${ }^{2}$ and Nikolai P. Pokhilenko ${ }^{2}$ \\ ${ }^{1}$ CODES and School of Earth Sciences, University of Tasmania, Hobart, TAS, Australia \\ ${ }^{2}$ Institute of Geology and Mineralogy, Novosibirsk, Russia \\ ${ }^{3}$ School of Earth Sciences, University of Melbourne, VIC 3010, Australia
}

\begin{abstract}
"Kimberlites are regarded by ...the geological and geochemical community with an aura of glamour and mystique" (Eggler, 1989). Diamonds are definitely a "glamorous" component, but what causes "mystique"? After almost a century of research, the true nature of kimberlite parental melts, their origin and evolution are still debated, with numerous recent empirical, theoretical and experimental studies (e.g., Dalton and Presnall, 1998; Girnis and Ryabchikov, 2005; Gudfinnsson and Presnall, 2005; Harris et al., 2004; Kopylova et al., 2007; le Roex et al., 2003; Mitchell, 2008; Price et al., 2000). Modelling of kimberlite primary melts is tightly constrained by measured kimberlite rock compositions, even though "... .the kimberlitic rock is both a contaminated and altered sample of its parent melt" (Pasteris, 1984). Group-I kimberlite rocks worldwide form a tight clan of ultramafic compositions $(\mathrm{MgO}>20 \mathrm{wt} \%$; $\mathrm{Mg} \#>80$ ), with exceptionally high contents of volatiles $\left(\mathrm{CO}_{2}+\mathrm{H}_{2} \mathrm{O}>6 \mathrm{wt} \%\right)$ and incompatible trace elements (e.g., $\mathrm{La}>50 \mathrm{ppm}$ ), but very low contents of "basaltic" components $\left(\mathrm{Na}_{2} \mathrm{O}<0.4 \mathrm{wt} \%\right.$ and $\mathrm{Al}_{2} \mathrm{O}_{3}<5$ $w t \%)$ and elements of moderate incompatibility (e.g., $\mathrm{Yb}<1.5 \mathrm{ppm}$; so-called "garnet" signature). Chemical trends within the clan are attributed to varying proportions of olivine (present as phenocrysts and xenocrysts) and groundmass carbonate. Unfortunately, the effects of contamination and alteration remain difficult to quantify, thus making modelling of parental kimberlite melts from whole rock compositions problematic.
\end{abstract}

The commonly accepted model ultramafic composition of kimberlite primary melts generates several internal inconsistencies with other modelling results, notably melt temperature and rheology, magma source compositions and melting conditions, and style of magma ascent and emplacement. An ultramafic parent melt composition 1) is not in equilibrium with olivine phenocrysts; 2) requires high degrees of partial melting that contradict enrichment in incompatible elements and volatiles; 3) requires high melting temperatures that are not confirmed by estimates of melt temperature during kimberlite emplacement; 4) is inconsistent with inferred low magma viscosity and density. Apart from problems with the ultramafic composition, two other "trademarks" of primary kimberlite melt - ini- tially low sodium and high water abundances - may also be questionable as these signatures are easily compromised by postmagmatic alteration. In other words, current models rely on interpretations that have arisen over years from demonstrably defective basic assumptions.

In the last five years we have contributed to this debate on the basis of new results from the Udachnaya-East pipe in Siberia (e.g., Golovin et al., 2007; Kamenetsky et al., 2004; Kamenetsky et al., 2007a, b). This pipe is famous for its high diamond grade and abundance of uniquely fresh mantle and crustal xenoliths. Another unique observation is that kimberlites taken from deep mine levels $(>350 \mathrm{~m}$ depth) have a salty taste! This property is highly unusual for magmatic rocks and, indeed, is not shared by kimberlite from shallower mine horizons in the same pipe or the nearby Udachnaya-West pipe, or by any other kimberlite. The saltiness is caused by abundant chloride crystals (halite and sylvite) in the groundmass (Fig. 1). The presence of these chlorides, and of water-soluble Na-K-Ca carbonates (shortite and zemkorite), explains the coupled enrichment in both sodium and chlorine (up to $6.2 \mathrm{wt} \%$ of each $\mathrm{Na}_{2} \mathrm{O}$ and $\mathrm{Cl}$ ) (Fig. 2).

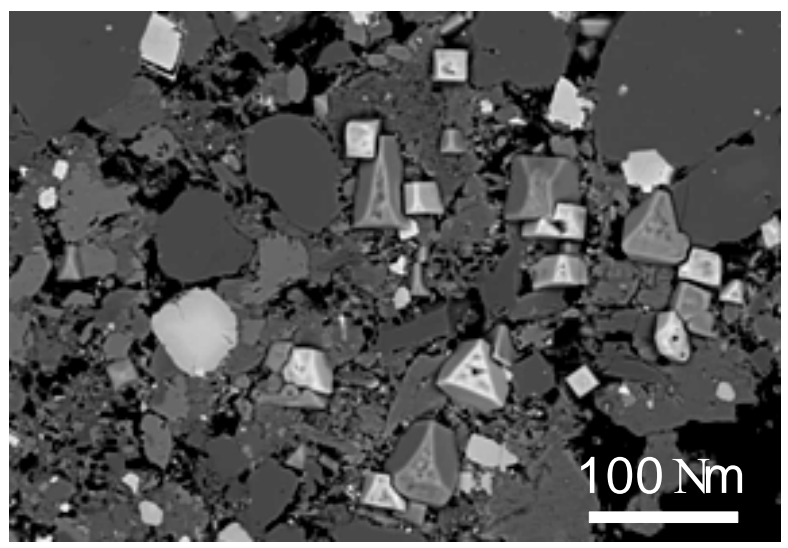

Fig. 1. BSE image of polished surface of the Udachnaya-East kimberlite sample showing abundant halite (grey) and sylvite (white), recrystallised in air, in the alkali-carbonate groundmass cementing olivine.

In contrast to almost every other kimberlite described to date, these rocks are $\mathrm{H}_{2} \mathrm{O}$-poor $(0.2 \mathrm{wt} \%$ in most Na- 
and Cl-enriched samples, Table 1), containing no primary or secondary serpentine, nor any other significant $\mathrm{H}_{2} \mathrm{O}$-rich minerals, except for some minor groundmass phlogopite. The lack of $\mathrm{OH}$-bearing alteration and preservation of water-soluble salts implies that both syn- and post-magmatic alteration were minimal. All other chemical characteristics of these "salty" rocks, in particular, ultramafic compositions (28-36 wt\% MgO, 1000-1500 ppm Ni, 800-1400 ppm Cr), strong LREE enrichment and HREE depletion $(\mathrm{La} / \mathrm{Sm}=10-12 ; \mathrm{Gd} / \mathrm{Yb}=8-11)$ are typical of group-I kimberlites (Table 1, Fig. 3).

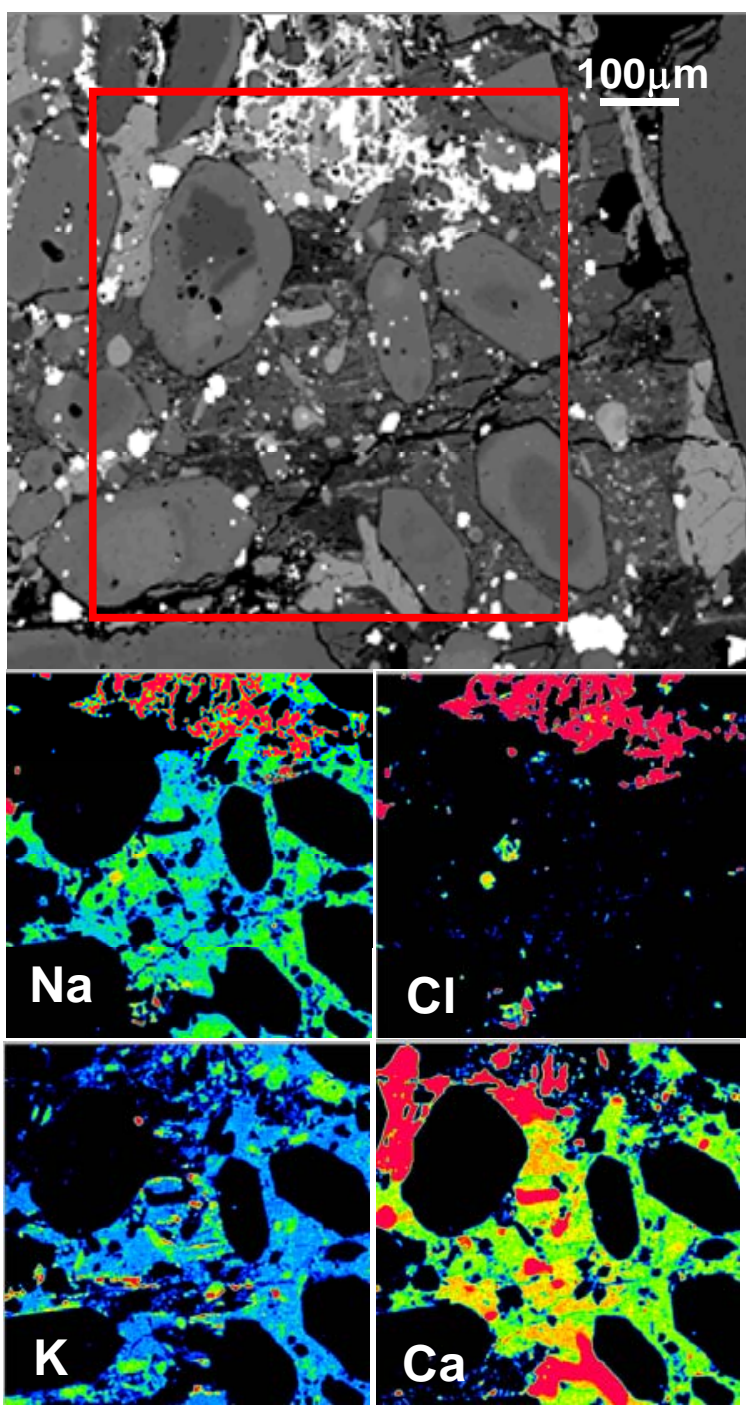

Fig. 2. BSE image and X-ray elemental maps showing distribution of chlorides, alkali carbonates, calcite and olivine in the Udachnaya-East kimberlite.

Based on the studies of melt/mineral inclusions and Sr$\mathrm{Nd}-\mathrm{Pb}$ isotope compositions of $\mathrm{Cl}-$ and alkali-rich groundmass components (Golovin et al., 2007; Kamenetsky et al., 2004; Kamenetsky et al., 2007a; Maas et al., 2005), we conclude that unusual characterisitcs of the Udachnaya-East kimberlite are inherited from the kimberlite parent melt. Our work suggests this melt is best represented by melt inclusions entrapped in the groundmass olivine and phlogopite at $660-760^{\circ} \mathrm{C}$ (Kamenetsky et al., 2004; Kamenetsky et al., 2007a). These inclusions strongly resemble the kimberlite groundmass in terms of assemblage of daughter minerals and lithophile trace element compositions (Fig. 3). Also such melt is represented by chloride-rich and carbonate-chloride segregations in the groundmass (Kamenetsky et al., 2007a).

\begin{tabular}{|l|ccccc|}
\hline & UE & SK & JK & KK & GK \\
\hline $\mathrm{SiO}_{2}$ & 26.71 & 30.59 & 32.31 & 29.04 & 25.64 \\
$\mathrm{TiO}_{2}$ & 1.25 & 2.25 & 0.89 & 2.01 & 3.60 \\
$\mathrm{Al}_{2} \mathrm{O}_{3}$ & 1.75 & 2.86 & 1.99 & 2.13 & 1.41 \\
$\mathrm{FeO}_{\mathrm{t}}$ & 8.09 & 8.60 & 7.70 & 8.59 & 10.24 \\
$\mathrm{MgO}$ & 31.33 & 28.06 & 32.56 & 28.79 & 33.10 \\
$\mathrm{CaO}$ & 12.19 & 9.36 & 8.70 & 11.09 & 10.64 \\
$\mathrm{Na}_{2} \mathrm{O}$ & 3.23 & 0.14 & 0.13 & 0.19 & 0.09 \\
$\mathrm{~K}_{2} \mathrm{O}$ & 1.33 & 1.26 & 0.28 & 1.05 & 0.20 \\
$\mathrm{P}_{2} \mathrm{O}_{5}$ & 0.49 & 0.54 & 0.44 & 1.66 & 0.49 \\
$\mathrm{SO}_{3}$ & 0.48 & 0.30 & n.d. & n.d. & n.d. \\
$\mathrm{Cl}$ & 2.38 & n.d. & n.d. & n.d. & n.d. \\
$\mathrm{SrO}_{\mathrm{BaO}}$ & 0.10 & 0.09 & 0.06 & 0.15 & 0.10 \\
$\mathrm{Ba}_{2} \mathrm{O}$ & 0.13 & 0.11 & n.d. & 0.15 & 0.09 \\
$\mathrm{CO}_{2}$ & 9.42 & 9.55 & 7.44 & 7.78 & 12.82 \\
$\mathrm{Total}$ & 99.26 & 99.43 & 98.76 & 98.78 & 98.42 \\
\hline
\end{tabular}

Table 1. Average compositions of kimberlites from Udachanaya-East (UE, 9 samples with $\mathrm{H}_{2} \mathrm{O}<1$ wt\%), Siberian craton (SK, $\mathrm{n}=31$ ); Jericho pipe, Slave Craton (JK, $\mathrm{n}=57)$; Kimberley, S. Africa (KK, $\mathrm{n}=28)$ and Majuagaa, SW. Greenland (GK, $n=19)$.

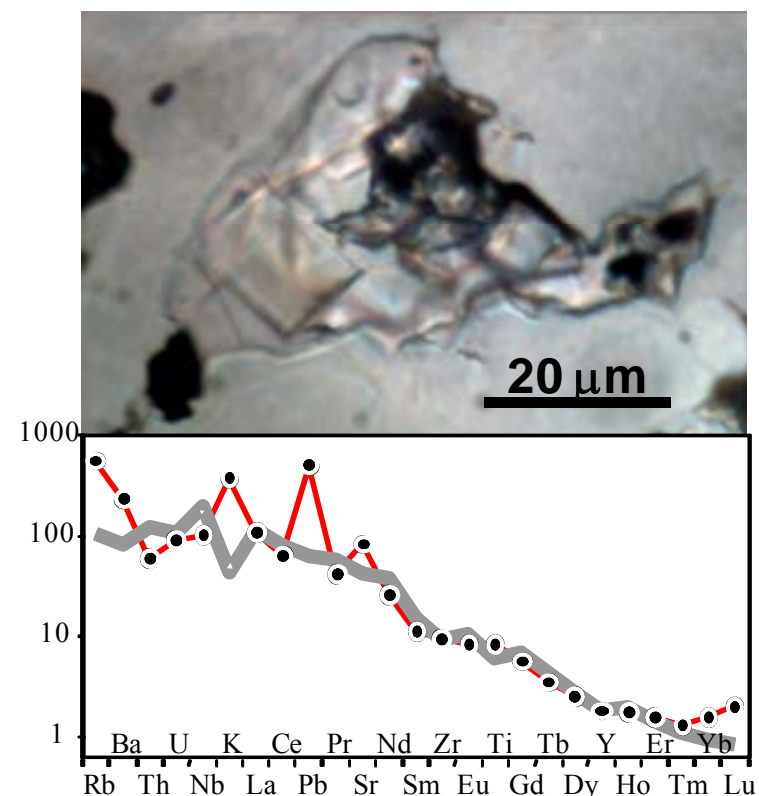

Fig. 3. Typical alkali carbonate-chloride melt inclusion in olivine and primitive mantle-normalised average compositions of such melt inclusions and host kimberlites (grey) from the Udachnaya-East pipe.

An often-raised criticism of our interpretations relates to the possible origin of salt in the Udachnaya-East from well-known carbonate-evaporite sequences preserved in parts of the Siberian Craton. Arguments against such a link, i.e. an origin of alkali- and chlorine-enrichment from assimilation of sedimentary evaporite-carbonate include (1) the absence of 
evaporites within the Udachnaya pipe host rocks down to $1700 \mathrm{~m}$ in boreholes, (2) the absence of evaporiterelated fragments or xenoliths in the kimberlite; and (3) the absence of similar compositions in the UdachnayaWest and other kimberlite pipes from the same cluster. The mantle origin of the "salty" component in the kimberlite melt is supported by its intimate association with abundant carbonate and olivine components in the groundmass (Fig. 1, 2), whereas the aluminosilicate (basaltic) component is virtually absent. Further evidence comes from neon isotope studies on groundmass olivine containing carbonate-chloride melt inclusions (Sumino et al., 2006). Crustal-level contamination of the kimberlite melt is further ruled out by the low ${ }^{87} \mathrm{Sr} /{ }^{86} \mathrm{Sr}(\approx 0.7031)$ in melt-derived perovskite (Maas et al., 2008). Mantle xenoliths and macrocrysts from the studied kimberlite samples show strong evidence of Na-K-Ca-Cl-S alteration and contain carbonate-chloride melt inclusions (Golovin et al., 2008). Similar signatures in Udachnaya- East eclogite xenoliths have been attributed to a metasomatic event in the upper mantle, after xenoliths' incorporation in the kimberlite magma (Misra et al., 2004). Minerals typical of the Udachnaya-East kimberlite groundmass and melt inclusions have also been found in other kimberlites (Kamenetsky et al., 2008), carbonatites, diamonds and chondrites. We thus infer that the "dry" alkali-rich carbonate-chloride component is of primary mantle origin. We suggest that a proto-kimberlitic melt high in alkalies, $\mathrm{CO}_{2}$ and $\mathrm{Cl}$ may provide a viable alternative to the currently favored ultramafic magma composition. A "salty" kimberlite composition could explain trace element signatures consistent with low degrees of partial melting, low temperatures of crystallisation and exceptional rheological properties responsible for fast ascent and the ability of the magma to carry a great load of nodules and crystals.

Important open questions remain. Why are easily soluble minerals, such as the carbonates and chlorides we describe, preserved in this kimberlite, and why is olivine free of alteration serpentine ? Why are such features not observed in other kimberlites? At the meeting, we will present new data on the distribution of alkali elements, carbonate and chlorine in other kimberlite rocks prior to their alteration (Kamenetsky et al., 2008).

\section{References}

Dalton, J.A. and Presnall, D.C., 1998. The continuum of primary carbonatitic-kimberlitic melt compositions in equilibrium with lherzolite: Data from the system $\mathrm{CaO}-\mathrm{MgO}-\mathrm{Al}_{2} \mathrm{O}_{3}-\mathrm{SiO}_{2}-\mathrm{CO}_{2}$ at $6 \mathrm{GPa}$. Journal of Petrology, 39: 1953-1964.

Eggler, D.H., 1989. Kimberlites: how do they form? In: J. Ross, et al. (Eds), Kimberlites and related rocks: their composition, occurrence, origin and emplacement, pp. 489-504.

Girnis, A.V. and Ryabchikov, I.D., 2005. Conditions and mechanisms of generation of kimberlite magmas. Geology of Ore Deposits, 47: 476-487.

Golovin, A.V. et al., 2008. Alkali- and Cl-enriched carbonate-silicate melt inclusions in sheared lherzolite xenoliths from unaltered kimberlites of the Udachnaya-East pipe (Yakutia), 9th IKC, Extended Abstract No. 9IKC-A-00061.

Golovin, A.V. et al., 2007. Melt inclusions in olivine phenocrysts in unaltered kimberlites from the Udachnaya-East pipe, Yakutia: Some aspects of kimberlite magma evolution during late crystallization stages. Petrology, 15: 168-183.

Gudfinnsson, G.H. and Presnall, D.C., 2005. Continuous gradations among primary carbonatitic, kimberlitic, melilititic, basaltic, picritic, and komatiitic melts in equilibrium with garnet lherzolite at 3-8 GPa. Journal of Petrology, 46: 1645-1659.

Harris, M. et al., 2004. Geochemistry of the Uintjiesberg kimberlite, South Africa: petrogenesis of an offcraton, group I, kimberlite. Lithos, 74: 149-165.

Kamenetsky, M.B. et al., 2004. Kimberlite melts rich in alkali chlorides and carbonates: a potent metasomatic agent in the mantle. Geology, 32: 845848.

Kamenetsky, V.S. et al., 2007a. Chloride and carbonate immiscible liquids at the closure of the kimberlite magma evolution (Udachnaya-East kimberlite, Siberia). Chemical Geology, 237: 384-400.

Kamenetsky, V.S. et al., 2007b. Carbonate-chloride enrichment in fresh kimberlites of the UdachnayaEast pipe, Siberia: A clue to physical properties of kimberlite magmas? Geophysical Research Letters, 34(9): L09316, doi:10.1029/2007GL029389.

Kamenetsky, V.S. et al., 2008. Alkali carbonates and chlorine in kimberlites from Canada and Greenland: evidence from melt inclusions and serpentine, 9th IKC, Extended Abstract No. 9IKC-A-00028.

Kopylova, M.G. et al., 2007. Searching for parental kimberlite melt. Geochimica et Cosmochimica Acta, 71: 3616-3629.

le Roex, A.P. et al., 2003. Petrogenesis of group I kimberlites from Kimberley, South Africa: evidence from bulkrock geochemistry. Journal of Petrology, 44: 22612286.

Maas, R. et al., 2005. Sr, $\mathrm{Nd}$, and $\mathrm{Pb}$ isotope evidence for a mantle origin of alkali chlorides and carbonates in the Udachnaya kimberlite, Siberia. Geology, 33: $549-552$.

Maas, R. et al., 2008. Low ${ }^{87} \mathrm{Sr} /{ }^{86} \mathrm{Sr}$ in kimberlitic perovskite - further evidence for recycled oceanic crust as a possible source of kimberlites, 9th IKC, Extended Abstract No. 9IKC-A-00296.

Misra, K.C. et al., 2004. Multi-stage metasomatism of diamondiferous eclogite xenoliths from the Udachnaya kimberlite pipe, Yakutia, Siberia. Contributions to Mineralogy and Petrology, 146: 696-714.

Mitchell, R.H., 2008. Petrology of hypabyssal kimberlites: Relevance to primary magma compositions,. Journal of Volcanology and Geothermal Research: doi:10.1016/j.jvolgeores.2007.12.024.

Pasteris, J.D., 1984. Kimberlites: Complex mantle melts. Annual Review of Earth and Planetary Sciences, 12: 133-153.

Price, S.E. et al., 2000. Primitive magma from the Jericho Pipe, NWT, Canada: Constraints on primary kimberlite melt chemistry. Journal of Petrology, 41: 789-808.

Sumino, H. et al., 2006. Deep mantle origin of kimberlite magmas revealed by neon isotopes. Geophysical Research Letters, 33(16): L16318, doi: 10.1029/2006GL027144. 